\title{
Factors influencing the performance of phosphites on the control of coffee leaf rust
}

\author{
Jaime Honorato Júnior ${ }^{1}$ (D), Daniel Debona ${ }^{1}$ (D) Laércio Zambolim ${ }^{1}$ (D) Fabrício Ávila Rodrigues ${ }^{1, *}$ (D) \\ 1. Universidade Federal de Viçosa - Departamento de Fitopatologia - Viçosa (MG), Brazil. \\ Received: Apr. 23, 2020 | Accepted: Oct. 6, 2020 \\ Section Editor: Robson Di Piero \\ *Corresponding author: fabricio@ufv.br \\ How to cite: Honorato Júnior, J., Debona, D., Zambolim, L. and Rodrigues, F. A. (2021). Factors influencing the performance of phosphites on \\ the control of coffee leaf rust. Bragantia, 80, e0221. https://doi.org/10.1590/1678-4499.20200176
}

\begin{abstract}
This study investigated the effect of different phosphites on the control of coffee leaf rust (CLR) caused by Hemileia vastatrix, considered the major disease affecting coffee yield worldwide. Three-month-old coffee plants were sprayed with two doses each of the phosphite solutions (standard and double), as follows: $\mathrm{K}\left(40 \% \mathrm{P}_{2} \mathrm{O}_{5} ; 1.5\right.$ and $\left.3 \mathrm{~mL} \cdot \mathrm{L}^{-1}\right), \mathrm{K}\left(30 \% \mathrm{P}_{2} \mathrm{O}_{5} ; 3\right.$ and $\left.6 \mathrm{~mL} \cdot \mathrm{L}^{-1}\right), \mathrm{Cu}\left(2.5 \mathrm{and} 5 \mathrm{~mL} \cdot \mathrm{L}^{-}\right.$ $\left.{ }^{1}\right), M n+Z n\left(3\right.$ and $6 \mathrm{~mL} \cdot \mathrm{L}^{-1}$ ) and $\mathrm{Na}\left(3\right.$ and $\left.6 \mathrm{~mL} \cdot \mathrm{L}^{-1}\right) 24 \mathrm{~h}$ before being inoculated with $\mathrm{H}$. vastatrix. Leaves were not washed or washed with deionized water after the foliar phosphites spray. Plants sprayed with water served as the control treatment. Inoculation was performed on the abaxial side of the first pair of expanded leaves using a camel hairbrush with a suspension of urediniospores ( $1 \mathrm{mg}$ per leaf). All phosphites applied at the standard doses (from 1.5 to $3 \mathrm{~mL} \cdot \mathrm{L}^{-1}$ ) reduced the total number of pustules (TNP) per leaf by $28-69 \%$ regardless of washing treatment. The biggest reductions were observed for $\mathrm{Cu}$ phosphite, which decreased the TNP per leaf by 60 and $69 \%$ without and with leaf washing, respectively. A similar trend was observed when the double doses of phosphites (from 3 to $6 \mathrm{~mL} \cdot \mathrm{L}^{-1}$ ) were $\mathrm{used}$, though $\mathrm{Na}$ phosphite without leaf washing and $\mathrm{Mn} / \mathrm{Zn}$ phosphite without and with leaf washing were not efficient to reduce the TNP per leaf. Without leaf washing, only Cu and Na phosphites decreased CLR severity at the standard doses (53-61\%), whereas all phosphites, except the Mn/ Zn phosphite, reduced CLR severity at the double dose. The CLR severity was decreased using $\mathrm{K} 30 \%, \mathrm{~K} 40 \%$ and Cu phosphites when applied at the standard doses with leaf washing (41-59\%). With double doses, only Cu and Na phosphites decreased CLR severity by $55 \%$ for both treatments. In conclusion, the efficiency of the phosphites for CLR control varied according to the accompanying cation, dose and washing conditions. The Cu phosphite resulted in the best CLR control regardless of the dose used and the washing conditions.
\end{abstract}

Key words: Coffea arabica L., disease control, induced resistance.

Coffee is one of the most traded commodities worldwide (CrumLey 2013; Vega et al. 2003; Zambolim 2016). The occurrence of foliar and root diseases is one key factor limiting coffee yield. Coffee leaf rust (CLR), caused by the biotrophic fungus Hemileia vastatrix Berkeley \& Broome, is among the most important foliar diseases affecting Coffea arabica globally (Waller et al. 2007). Yield reduction can range from 35 to $50 \%$ with the occurrence of premature leaf fall, the death of branches and low photosynthesis rates in the previous year (Zambolim 2016; Waller et al. 2007). Pale yellow spots on the abaxial side of the leaves that develop into orange-yellow pustules that often coalesce with each other are typical symptoms of CLR (Kushalappa and Eskes 1989; Zambolim 2016). Triazoles and strobilurins, sprayed on the leaves or applied into the soil, are the major fungicides used for CLR control (Zambolim 2016).

In the context of sustainable agriculture, the discovery of alternative methods for CLR control is urgently needed. Phosphite based compounds are marketed as foliar fertilizers and disease resistance inducers, their metal salts are effective in controlling diseases caused by oomycetes, including Phytophthora spp. (Machinandiarena et al. 2012; Dalio et al. 2014; Adaskaveg et al. 2015) and Plasmopara viticola (Pereira et al. 2012) as well as fungi such as Rhizoctonia solani, Alternaria 
alternata, Fusarium spp., and Sclerotinia sclerotiorum (Reuveni et al. 2003; Sharaf and Farrag 2004; Lobato et al. 2010; Cerqueira et al. 2017; Fagundes-Nacarath et al. 2018). The major action of phosphites is on the inhibition of pathogen mycelial growth through the rupture of their cell wall besides affecting the physiology of plants towards a potentiation of host defense responses, such as the production of phenolics, phytoalexins and lignin as well as high activities of chitinase, $\beta$-1,3-glucanase, peroxidase, polyphenoloxidase, and phenylalanine ammonia-lyase (Eshraghi et al. 2011; Jackson et al. 2000; Reuveni 1997; Fagundes-Nacarath et al. 2018; Novaes et al. 2019; Panicker and Gangadharan 1999; Daniel and Guest 2006; Dalio et al. 2014).

Considering the importance of CLR to negatively impact coffee yield and the need of new control methods to reduce the amount of fungicide sprays, the present study aimed to examine the effect of potassium $(\mathrm{K})$, copper $(\mathrm{Cu})$, manganese $(\mathrm{Mn})+\operatorname{zinc}(\mathrm{Zn})$ and sodium $(\mathrm{Na})$ phosphites on the control of CLR.

Three-month-old coffee plants with three pairs of leaves ('Catuaí Vermelho IAC 144', susceptible to H. vastatrix) grown in plastic pots containing $1 \mathrm{~kg}$ of substrate (soil, manure and sand in the proportion of 2.5:1:0.5) in a greenhouse (temperature of $30 \pm 2{ }^{\circ} \mathrm{C}$, relative humidity of $70 \pm 5 \%$ and natural photosynthetically active radiation), were sprayed ( $20 \mathrm{~mL}$ per plant) with phosphite solutions as follows: $\mathrm{K}$ [Fitofos-K-Plus $\left(40 \% \mathrm{P}_{2} \mathrm{O}_{5}\right.$ and $20 \% \mathrm{~K}_{2} \mathrm{O} ; 1.5$ and $\left.3 \mathrm{~mL} \cdot \mathrm{L}^{-1}\right)$ ] and Phosfik PK $\left(30 \% \mathrm{P}_{2} \mathrm{O}_{5}\right.$ and $20 \% \mathrm{~K}_{2} \mathrm{O} ; 3$ and $\left.6 \mathrm{~mL} \cdot \mathrm{L}^{-1}\right), \mathrm{Cu}$ [Phosfik Cu $4\left(22 \% \mathrm{P}_{2} \mathrm{O}_{5}, 4 \% \mathrm{Cu}, 1.76 \% \mathrm{~S}\right.$ and $11 \% \mathrm{~N} ; 2.5$ and $\left.5 \mathrm{~mL} \cdot \mathrm{L}^{-1}\right)$ ], Mn+Zn [Phosfik Mn+Zn $\left[30 \% \mathrm{P}_{2} \mathrm{O}_{5}, 3 \% \mathrm{~N}, 5 \% \mathrm{Mn}\right.$ and $5 \% \mathrm{Zn} ; 3$ and $\left.\left.6 \mathrm{~mL} \cdot \mathrm{L}^{-1}\right]\right)$, and Na phosphite $\left(\mathrm{H}_{10} \mathrm{Na}_{2} \mathrm{O}_{8} \mathrm{P}^{+} ; 3\right.$ and $\left.6 \mathrm{~mL} \cdot \mathrm{L}^{-1}\right)$. The phosphite solutions were sprayed at the adaxial and abaxial leaf surfaces of each plant $24 \mathrm{~h}$ before inoculation with $\mathrm{H}$. vastatrix. Plants were fertilized with a nutritive solution (Honorato Júnior et al., 2015) twice a week. Phosphite solutions, prepared using deionized water, were applied at standard (from 1.5 to $3 \mathrm{~mL} \cdot \mathrm{L}^{-1}$ ) and double (from 3 to $6 \mathrm{~mL} \cdot \mathrm{L}^{-1}$ ) doses. The standard doses used for each phosphite were based on the manufacturers' recommendations. $\mathrm{A} \mathrm{CO}_{2}$ pressurized backpack sprayer with a flat fan nozzle (XR 11002 ,

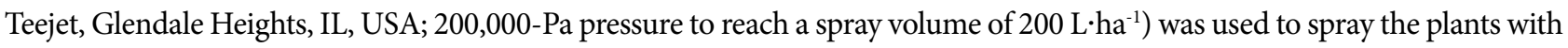
the phosphite solutions. Plants sprayed with deionized water served as the control treatment. Leaves were either not washed or washed with deionized water ( $5 \mathrm{~mL}$ per leaf during $10 \mathrm{~min}$ using a plastic syringe at $30 \mathrm{~min}$ ) after the spray of phosphite solutions.

Plants were inoculated with $H$. vastatrix $24 \mathrm{~h}$ after washing or not the leaves with water. The inoculation was performed on the abaxial side of the first pair of expanded leaves per each plant by using a camel hairbrush with a suspension of urediniospores (1 mg per leaf) according to Honorato Júnior et al. (2015). After inoculation, plants were transferred to a moist growth chamber (temperature of $22 \pm 1{ }^{\circ} \mathrm{C}$ and relative humidity of $90 \pm 5 \%$ ) in the dark for $48 \mathrm{~h}$. After that period, plants were transferred to a growth chamber (temperature of $22^{\circ} \mathrm{C}$, relative humidity of $65 \pm 5 \%$ and photoperiod of $12 \mathrm{~h}$ using fluorescent light $\left.\left[7.35 / \mathrm{Wm}^{2}\right]\right)$ until the end of the experiments.

The total number of pustules (TNP) per leaf and CLR severity were evaluated 30 days after inoculation. The CLR severity was evaluated in each leaf according to the diagrammatic scale proposed by Kushalappa (1978). This scale consists of three coffee leaves with 30, 50 and 70\% of CLR severity on each leaf. Each leaf has a known area of 1,3,5,7 and 10\% occupied by individual pustules.

A $6 \times 2 \times 2$ factorial experiment consisting of six foliar treatments (plants sprayed with water [control] or with solutions of $\mathrm{K} 40 \%, \mathrm{~K} \mathrm{30 \% ,Cu}, \mathrm{Mn}+\mathrm{Zn}$, and $\mathrm{Na}$ ), washed and nonwashed leaves and phosphite doses (standard and double) was arranged in a completely randomized design with ten replications. Each replication corresponded to a plastic pot containing one plant. The experiment was repeated. Data from TNP per leaf and CLR severity from the two experiments were analyzed using the MIXED procedure of the SAS software (Release 8.02 Level $02 \mathrm{M} 0$ for Windows, SAS Institute) to determine if data from the experiments could be combined (Moore and Dixon 2015). Data was checked for normality and homogeneity of variance and subjected to analysis of variance (ANOVA) using the generalized linear model and the Minitab software (version 18; Minitab Corporation).

Based on ANOVA, the foliar treatments were the most significant factor $(\mathrm{p}<0.001)$ influencing the TNP per leaf and CLR severity (Table 1). The interaction among washing, foliar treatments and doses was significant for both TNP per leaf and CLR severity $(\mathrm{p}<0.01)$, indicating that the performance of phosphites for CLR control was affected by the doses and washing factors.

All phosphites applied at the standard doses reduced the TNP per leaf by $28-69 \%$, regardless of the washing treatment (Fig. 1a and b). The greatest reductions were observed for $\mathrm{Cu}$ phosphite, which decreased the TNP per leaf by 60 and $69 \%$ without and with leaf washing, respectively. When applied the double dose, only Na phosphite without leaf washing and $\mathrm{Mn} / \mathrm{Zn}$ phosphite with and without leaf washing did not reduce the TNP. The TNP decreased for K phosphite $40 \%$ applied at the double dose, relative to the standard dose without leaf washing. Leaf washing decreased the performance of $\mathrm{K}$ phosphite $40 \%$ at the double dose and $\mathrm{Mn} / \mathrm{Zn}$ Phi at the standard dose. 
Table 1. Analysis of variance for the effects of washing, foliar treatments, doses, and their interactions for the total number of pustules per leaf and coffee leaf rust (CLR) severity.

\begin{tabular}{ccc}
\hline \multirow{2}{*}{ Sources of variation } & \multicolumn{2}{c}{ F values } \\
\cline { 2 - 3 } & Total number of pustules per leaf & CLR severity \\
\hline Washing (W) & $0.28^{\text {ns }}$ & $0.34^{\text {ns }}$ \\
\hline Foliar treatments (FT) & $35.60^{* *}$ & $31.67^{* *}$ \\
\hline Doses (D) & $0.14^{\text {ns }}$ & $<0.01^{\text {ns }}$ \\
\hline W $\times$ FT & $1.18^{\text {ns }}$ & $2.97^{*}$ \\
\hline W $\times$ D & $<0.01^{\text {ns }}$ & $1.66^{\text {ns }}$ \\
\hline FT $\times$ D & $7.87^{* *}$ & $2.56^{*}$ \\
\hline W $\times$ FT $\times$ D & $4.23^{* *}$ & $7.78^{* *}$ \\
\hline$*, *$ and ns $=$ significant at the levels of probability of 1 and $5 \%$ and nonsignificant, respectively.
\end{tabular}

In general, $\mathrm{Cu}$ and $\mathrm{Na}$ phosphites were more efficient in reducing CLR severity. The $\mathrm{K}$ phosphites applied at the double dose (without leaf washing) and at standard dose (with leaf washing) also decreased CLR severity, which was reduced by doubling the dose of $\mathrm{K}$ phosphite $40 \%$ without leaf washing. The performance of $\mathrm{K} 30 \%$ and $40 \%$ phosphites were generally decreased by leaf washing.

The present study brings new pieces of evidence on the efficacy of different phosphites in the CLR control. The decrease in CLR symptoms herein reported is consistent with other studies that investigated the potential of phosphites in controlling coffee diseases. The control of CLR and brown eye spot by $\mathrm{Cu}, \mathrm{K}$ and $\mathrm{Mn}$ phosphites in field conditions was greater than $45 \%$ (Costa et al. 2014). Similarly, the area under the severity of coffee rust progress curve was decreased by $63 \%$ due to $\mathrm{Mn}$ Phi in a greenhouse study (Monteiro et al. 2016). However, results from the present study indicate that the effectiveness of phosphites in CLR control was largely dependent on the accompanying cation of the phosphite formulation, dose and washing.

The dependence of the accompanying cation in the efficiency of phosphite in disease control has been recorded in previous studies. While $\mathrm{Cu}$ and $\mathrm{Zn}$ phosphites were effective in controlling white mold in common bean plants (FagundesNacarath et al. 2018) and powdery mildew in eucalyptus seedlings (Silva et al. 2013), K phosphite was ineffective in the control of anthracnose in apple trees (Araujo et al. 2010), Verticillium wilt of cacao trees (Ribeiro Júnior et al. 2006), pink rot in potatoes (Al-Mughrabi et al. 2007) and late blight in tomatoes (Nascimento et al. 2008). In the present study, Cu phosphite provided the most consistent results in terms of CLR control since this phosphite was the most efficient in decreasing both TNP per leaf and CLR, regardless of the dose and washing treatments. The similar performance obtained between washed and nonwashed conditions indicates the higher tenacity of phosphite in the presence of $\mathrm{Cu}$. The fungitoxicity of $\mathrm{Cu}$ against H. vastatrix is well documented and cupric fungicides are recommended for CLR control (Costa et al. 2019). Besides its direct activity against plant pathogens, $\mathrm{Cu}$ makes up of regulatory proteins and plays a role in photosynthetic electron transport, mitochondrial respiration, oxidative stress responses, cell wall metabolism and hormone signaling (Zambolim 2016). In addition, $\mathrm{Cu}$ is a cofactor of many enzymes such as $\mathrm{Cu} / \mathrm{Zn}$ superoxide dismutase (SOD), cytochrome $c$ oxidase, amine oxidase, laccase, plastocyanin and polyphenol oxidase (Yruela 2005). Therefore, $\mathrm{Cu}$ may have an additive effect in the phosphite performance by its fungitoxicity or activating host defense responses against infection by $H$. vastatrix.

Contrasting with $\mathrm{Cu}$ phosphite, in some cases $\mathrm{K}$ phosphites $30 \%$ and $40 \%$ had reductions in their performance against CLR due to washing. It is the first evidence that phosphites are differentially affected by washing. Despite the absence of literature dealing with the effect of washing on phosphite's performance, the efficiency of pesticides is known to be affected by leaf washing. In soybeans, the rainfall simulation, even $120 \mathrm{~min}$ after fungicide application, decreased the Asian soybean rust control effectiveness (Stefanello et al. 2016). It is important to highlight that different factors may impact the effect of products employed in disease control, including plant genotype, product, adjuvant, leaf age, drop size and time of application (Stefanello et al. 2016). The results indicate that $\mathrm{Cu}$ afforded a better tenacity to phosphite than $\mathrm{K}$. Therefore, less removal of $\mathrm{Cu}$ phosphite deposits on coffee leaves should be expected due to rainfall under field conditions.

Dose stood out as a key factor influencing CLR control due to phosphite treatment. Interestingly, the efficiency of CLR control was sharply affected by the dose for some phosphites, however it did not affect others. The K phosphite $40 \%$ was particularly 


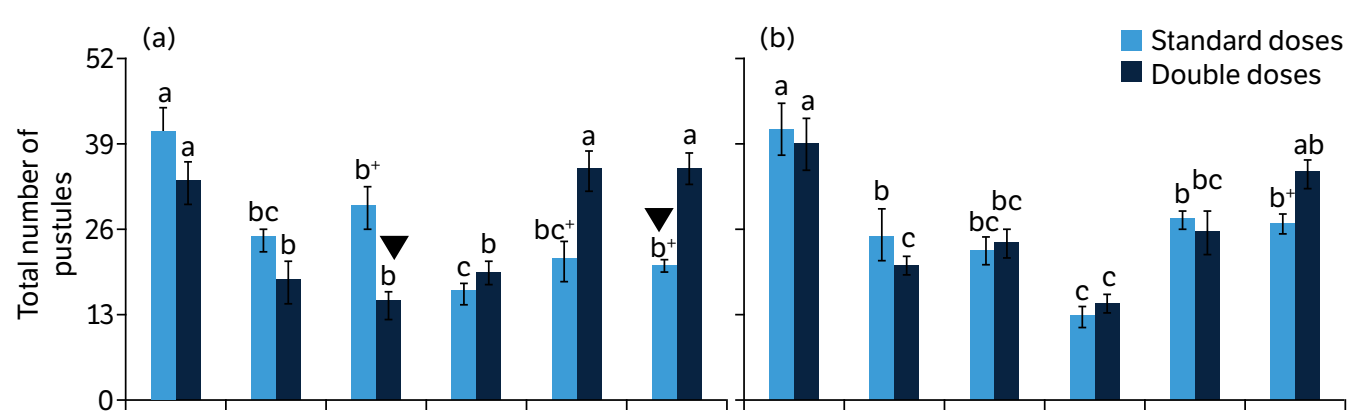

(c)

(d)



Figure 1. Total number of pustules per leaf and leaf rust severity (\%) determined in the leaves of coffee plants nonsprayed (control) or sprayed with phosphites (Phi) containing potassium (K) with 30 and $40 \%$ of $\mathrm{P}_{2} \mathrm{O}_{5}$ (K Phi $30 \%$ and $\mathrm{K}$ Phi $40 \%$, respectively), copper (Cu Phi), sodium (Na Phi) or manganese + zinc ( $\mathrm{Mn} / \mathrm{Zn}$ Phi). Phosphite solutions were applied at the standard and double doses. Leaves were not washed ( $a$ and $c$ ) or washed ( $b$ and $d$ ) with deionized water after foliar treatment. For each dose, means followed by different letters are significantly different ( $p \leq 0.05)$ according to Tukey's test. Means followed by asterisk $\left(^{\star}\right)$ for standard and double doses and inverted triangle ( $\boldsymbol{\nabla}$ ) for nonwashed and washed leaves are significantly different ( $p \leq 0.05)$ according to t-test. The bars represent the standard error of the means.

affected by it. At the standard dose without leaf washing, CLR severity was like the control treatment. In contrast, both TNP per leaf and CLR were reduced by $50 \%$ by doubling the dose of K phosphite $40 \%$. This may explain the contradictory results observed across different studies. Accordingly, K phosphite applied at the dose of $0.2 \mathrm{~mL} \cdot \mathrm{L}^{-1}$ did not control powdery mildew in eucalyptus (Bizi et al. 2008), whereas no symptoms and no plant mortality caused by Phytophthora plurivora were recorded in plants of common beech treated with $\mathrm{K}$ phosphite at the dose of $5 \mathrm{~mL} \cdot \mathrm{L}^{-1}$ (Dalio et al. 2014). However, the TNP increased when doubling the dose of $\mathrm{Na}$ and $\mathrm{Mn} / \mathrm{Zn}$ phosphites, which may be linked to the saline alkaline stress. The activity of photosystem II reaction center in plant leaves is decreased by salt stress, especially due to $\mathrm{Na}$, through reduced activity of the oxygen-evolving complex at the donor side of PSII and degradation of $\mathrm{D}_{1}$ protein on the acceptor side of the PSII (Zhang et al. 2018). Thus, phosphite formulations containing $\mathrm{Na}$ and $\mathrm{Mn} / \mathrm{Zn}$ may have decreased plant photosynthesis, which reduced carbohydrate supply for host defense reactions activated by phosphites, therefore nullifying the benefit of phosphite in CLR control.

A complex mode of action of phosphites in disease control can occur. They can act indirectly by inducing resistance in plants and directly by its fungitoxic activity against the pathogens (Dalio et al. 2014). Both mechanisms were found to operate in the phosphite afforded protection in coffee plants against CLR. In vitro trials revealed that the germination of urediniospores of $H$. vastatrix was completely inhibited by $\mathrm{Cu}, \mathrm{K}$ and $\mathrm{Mn}$ phosphites (Costa et al. 2014), indicating a direct effect of phosphite against the fungus. However, foliar sprays of Mn phosphite induced defenses in coffee seedlings, such as increased activities of ascorbate peroxidase, SOD and polyphenol oxidase in response to infection by $H$. vastarix (Monteiro et al. 2016). The last finding is somehow contrasting with the results of this work, in which $\mathrm{Mn} / \mathrm{Zn}$ did not decrease CLR severity. It is speculated that $\mathrm{Zn}$ could have counteracted the effect of Mn in disease suppression. Accordingly, Zn supplied as a soil drench increased the severity of powdery mildew in wheat through a combination of pathogen stimulation and host predisposition (Meyer 1950). The severity of aerial blight caused by $R$. solani in the leaves of soybean plants was greater as the Zn rates increased in the soil (Silva et al. 2012). Zinc can improve mycelial growth of several fungi species by increasing nitrogen uptake (Duffy 2007), therefore enhancing pathogen's aggressiveness. Phosphites, which were effective in CLR control, particularly Cu phosphite, may have reduced TNP per leaf and CLR severity in the present study by having both direct and indirect mechanisms against fungal infection. 
In conclusion, different formulations of phosphites were uncovered to control CLR, though their efficiency varied according to the accompanying cation, dose and washing conditions. The Cu phosphite was found to have a better performance on CLR control regardless of the dose used and the washing conditions. Washing had a negative effect in the performance of some phosphites, notably for K 30 and $40 \%$ phosphites. The CLR control provided by K30\% phosphite increased by doubling its dose, whereas Na and Mn/Zn phosphites had a worse performance when their dose increased. Therefore, $\mathrm{Cu}$ phosphite may represent a feasible tool to be included in the integrated management of CLR and further studies should be performed under field conditions to validate the findings herein reported.

\section{AUTHORS' CONTRIBUTION}

Conceptualization: Honorato Júnior J. and Zambolim L.; Methodology: Honorato Júnior J., Zambolim L. and Rodrigues F. A.; Investigation: Honorato Júnior J.; Writing - Original Draft: Honorato Júnior J., Debona D. and Rodrigues, F. A.; Writing - Review and Editing: Debona D. and Rodrigues F. A.; Funding Acquisition: Zambolim L.; Resources: Zambolim L.; Supervision: Zambolim L. and Rodrigues F. A.

\section{DATA AVAILABILITY STATEMENT}

Data will be available upon request

\section{FUNDING}

Conselho Nacional de Desenvolvimento Científico e Tecnológico

[http://doi.org/10.13039/501100003593]

Fundação de Amparo à Pesquisa do Estado de Minas Gerais

[http://doi.org/10.13039/501100004901]

Coordenação de Aperfeiçoamento de Pessoal de Nível Superior

[http://doi.org/10.13039/501100002322]

Finance Code 001.

\section{ACKNOWLEDGMENT}

Prof. Rodrigues thanks to the Conselho Nacional de Desenvolvimento Científico e Tecnológico (CNPq) for his fellowship.

\section{REFERENCES}

Adaskaveg, J. E., Hao, W. and Förster, H. (2015). Postharvest strategies for managing phytophthora brown rot of citrus using potassium phosphite in combination with heat treatments. Plant Disease, 99, 1477-1482. https://doi.org/10.1094/PDIS-01-15-0040-RE

Al-Mughrabi, K. I, Peters, R. D., Platt H. W. B., Moreau, G., Vikram, A., Poirier, R. and MacDonald, I. (2007). In-furrow applications of metalaxyl and phosphite for control of pink rot (Phytophthora erythroseptica) of potato in New Brunswick, Canada. Plant Disease, 91, 1305-1309. https://doi.org/10.1094/PDIS-91-10-1305 
Araujo, L., Valdebenito-Sanhueza, R. M. and Stadnik, M. J. (2010). Avaliação de formulações de fosfito de potássio sobre Colletotrichum gloeosporioides in vitro e no controle pós-infeccional da mancha foliar de Glomerella em macieira. Tropical Plant Pathology, $35,54-59$. https://doi.org/10.1590/S1982-56762010000100010

Bizi, R. M., Grigoletti Junior, A., Auer, C. G. and May-De Mio, L. L. (2008). Produtos alternativos no controle do oídio em mudas de eucalipto. Summa Phytopathologica, 34, 144-148. https://doi.org/10.1590/S0100-54052008000200006

Cerqueira, A., Alves, A., Berenguer, H., Correia, B., Gomez-Cadenas, A., Diez, J. J., Monteiro, P. and Pinto, G. (2017). Phosphite shifts physiological and hormonal profile of Monterey pine and delays Fusarium circinatum progression. Plant Physiology and Biochemistry, 114, 88-99. https://doi.org/10.1016/j.plaphy.2017.02.020

Costa, B. H. G., Resende, M. L. V., Ribeiro Júnior, P. M., Mathioni, S. M., Pádua, M. A. and Silva Júnior, M. B. (2014). Suppression of rust and brown eye spot diseases on coffee by phosphites and by-products of coffee and citrus industries. Journal of Phytopathology 162 , 635-642. https://doi.org/10.1111/.jph.12237

Costa, G. A., Lira, J. B., Freitas-Lopes, R. L. and Lopes, U. P. (2019). Tank mix application of copper hydroxide either with cyproconazole or pyraclostrobin fungicides reduced the control of coffee leaf rust. Crop Protection, 124,104856. https://doi.org/10.1016/j.cropro.2019.104856

CrumLey, M. L. (2013). The Price of liberalization: smallholder coffee producers in the era of globalization. Mediterranean Quarterly, 24, 102-128. https://doi.org/10.1215/10474552-2339480

Dalio, R. J. D., Fleischmann, F., Humez, M. and Osswald, W. (2014). Phosphite protects Fagus sylvatica seedlings towards Phytophthora plurivora via local toxicity, priming and facilitation of pathogen recognition. PLoS One, 9, e87860. https://doi.org/10.1371/journal.pone.0087860

Daniel, R. and Guest, D. (2006). Defense responses induced by potassium phosphonate in Phytophthora palmivora-challenged Arabidopsis thaliana. Physiological and Molecular Plant Pathology, 67, 194-201. https://doi.org/10.1016/j.pmpp.2006.01.003

Duffy, B. (2007). Zinc and plant disease. In L. E. Datnoff, W. H. Elmer and D. M. Huber (Eds.), Mineral Nutrition and Plant Disease. (p. 155172). Saint Paul: APS Press.

Eshraghi, L., Anderson, J., Aryamanesh, N., Shearer, B., McComb, J., Hardy, G. E. S. and O’Brien, P. A. (2011). Phosphite primed defence responses and enhanced expression of defence genes in Arabidopsis thaliana infected with Phytophthora cinnamomi. Plant Pathology, 60, 1086-1095. https://doi.org/10.1111/j.1365-3059.2011.02471.x

Fagundes-Nacarath, I. R. F., Debona, D., Brás, V. V., Silveira, P. R. and Rodrigues, F. A. (2018). Phosphites attenuate Sclerotinia sclerotioruminduced physiological impairments in common bean. Acta Physiologia Plantarum, 40, 198. https://doi.org/10.1007/s11738-018-2776-7

Honorato Júnior, J., Zambolim, L., Duarte, H. S. S., Aucique-Pérez, C. E. and Rodrigues, F. A. (2015). Effects of epoxiconozale and pyraclostrobin fungicides in the infection process of Hemileia vastatrix on coffee leaves as determined by chlorophyll $a$ fluorescence imaging. Journal of Phytopathology, 163, 968-977. https://doi.org/10.1111/jph.12399

Jackson, T. J., Burgess, T., Colquhoun, I. and Hardy, G. E. S. (2000). Action of the fungicide phosphite on Eucalyptus marginata inoculated with Phytophthora cinnamomi. Plant Pathology, 49, 147-154. https://doi.org/10.1046/j.1365-3059.2000.00422.x

Kushalappa, A. C. (1978). Uma escala para estimar a intensidade foliar de ferrugem do cafeeiro. Fitopatologia Brasileira, 3, 119.

Kushalappa, A. C. and Eskes, A. B. (1989). Coffee rust: epidemiology, resistance and management. Boca Raton: CRC Press.

Lobato, M. C., Olivieri, F. P., Daleo, G. R. and Andreu, A. B. (2010). Antimicrobial activity of phosphites against different potato pathogens. Journal of Plant Diseases Protection, 117, 102-109. https://doi.org/10.1007/BF03356343

Machinandiarena, M. F., Lobato, M. C., Feldman, M. L., Daleo, G. R. and Andreu, A. B. (2012). Potassium phosphite primes defense responses in potato against Phytophthora infestans. Journal of Plant Physiology, 169, 1417-1424. https://doi.org/10.1016/j.jplph.2012.05.005 
Meyer, H. (1950). Ueber den Einfluss von Cadmium auf die Krankheitsbereitschaft des Weizens für Erysiphe graminis tritici Marchal. Doctoral Thesis. https://doi.org/10.3929/ethz-a-000190527

Monteiro, A. C. A., Resende, M. L. V., Valente, T. C. T., Ribeiro Júnior, P. M., Pereira, V. F., Costa, J. R. and Silva, J. A. G. (2016). Manganese phosphite in coffee defence against Hemileia vastatrix, the coffee rust fungus: biochemical and molecular analyses. Journal of Phytopathology, 164, 1043-1053. https://doi.org/10.1111/jph.12525

Moore, K. J. and Dixon, P. M. (2015). Analysis of combined experiments revisited. Agronomy Journal, 107, $763-771$.

Nascimento, A. R., Fernandes, P. M., Rocha, M. R. and Silva, E. A. (2008). Fontes de fosfito e acibenzolar-S-metil no controle de doenças e produtividade do tomateiro. Bioscience Journal, 24, 53-59.

Novaes, M. I. C., Debona, D., Fagundes-Nacarath, I. R. F., Brás, V. V. and Rodrigues, F. A. (2019). Physiological and biochemical responses of soybean to white mold affected by manganese phosphite and fluazinam. Acta PhysiologiaePlantarum, 41, 186. https://doi.org/10.1007/s11738-019-2976-9

Panicker, S. and Gangadharam, K. (1999). Controlling downy mildew of maize caused by Peronosclerospora sorghi by foliar sprays of phosphonic acid compounds. Crop Protection, 18, 115-118. https://doi.org/10.1016/S0261-2194(98)00101-X

Pereira, V. F., Resende, M. L. V., Ribeiro Júnior, P. M., Regina, M. A., Mota, R. V. and Vitorino, L. R. R. (2012). Fosfito de potássio no controle do míldio da videira e características físico-químicas de uvas Merlot. Pesquisa Agropecuária Brasileira, 47, 1581-1588. https:// doi.org/10.1590/S0100-204X2012001100004

Reuveni, M. (1997). Post-infection applications of $\mathrm{K}_{3} \mathrm{PO}_{3}$, phosphorous acid and dimethomorph inhibit development of downy mildew caused by Plasmopara viticola on grapevines. Journal of Small Fruit \& Viticulture, 5, 27-38. https://doi.org/10.1300/J065v05n02_03

Reuveni, M., Sheglov, D. and Cohen, Y. (2003). Control of moldy-core decay in apple fruits by $\beta$-aminobutyric acids and potassium phosphites. Plant Disease, 87, 933-936. https://doi.org/10.1094/PDIS.2003.87.8.933

Ribeiro Júnior, P. M., Resende, M. L. V., Pereira, R. B., Cavalcanti, F. R., Amaral, D. R. and Pádua, M. A. (2006). Fosfito de potássio na indução de resistência a Verticillium dahliae Kleb. em mudas de cacaueiro (Theobroma cacao L.). Ciência e Agrotecnologia, 30, 629636. https://doi.org/10.1590/S1413-70542006000400006

Sharaf, E. F. and Farrag, A. A. (2004). Induced resistance in tomato plants by IAA against Fusarium oxysporum lycopersici. Polish Journal of Microbiology, 53, 111-116.

Silva, I. T., Rodrigues, F. A. and Baroni, J. C. P. (2012). Effect of soil applied zinc and manganese on the development of rhizoctonia aerial blight of soybean. Journal of Phytopathology, 160, 135-138. https://doi.org/10.1111/j.1439-0434.2011.01870.x

Silva, A. C., Resende, M. L. V., Souza, P. E., Silva, N. C. N., Silva Júnior, M. B. and Vitorino, L. R. R. (2013). Coffee-leaf extract and phosphites on the curative control of powdery mildew in eucalyptus mini-stumps. Forest Pathology, 43, 297-305. https://doi.org/10.1111/efp.12030

Stefanello, M. T., Balardin, R. S., Minuzzi, S. G., Favera, D. D., Marques, L. S., Pezzini, D. T. and Ebone, A. (2016). Effect of the interaction between fungicide application time and rainfall simulation interval on Asian soybean rust control effectiveness. Semina: Ciências Agrárias, 37, 3881-3892. https://doi.org/10.5433/1679-0359.2016v37n6p3881

Vega, F. E., Rosenquist, E. and Collins, W. (2003) Global project needed to tackle coffee crisis. Nature, 425, 343. https://doi.org/10.1038/425343a

Waller, J. M., Bigger, M. and Hillocks, R. J. (2007). Coffee pests, diseases and their management. Egham: CAB International. https://doi. org/10.1079/9781845931292.0000

Yruela, I. (2005). Copper in plants. Brazilian Journal of Plant Physiology, 17, 145-156. https://doi.org/10.1590/S1677-04202005000100012 Zambolim, L. (2016). Current status and management of coffee leaf rust in Brazil. Tropical Plant Pathology, 41, 1-8. https://doi.org/10.1007/ s40858-016-0065-9

Zhang, H.H., Xu, N., Wu, X., Wang, J., Ma, S., Li, X. and Sun, G. (2018). Effects of four types of sodium salt stress on plant growth and photosynthetic apparatus in sorghum leaves. Journal of Plant Interactions, 13, 506-513. https://doi.org/10.1080/17429145.2018.1526978 